\title{
ZASTOSOWANIE NARZĘDZI GIS W EDUKACJI Z ZAKRESU GOSPODARKI PRZESTRZENNEJ I OCHRONY ŚRODOWISKA
}

\begin{abstract}
Zarys treści: Celem artykułu było wskazanie możliwości zastosowania narzędzi Systemów Informacji Geograficznej (GIS) w edukacji na poziomie kształcenia wyższego, na przykładzie prac dyplomowych realizowanych na Uniwersytecie Przyrodniczym w Poznaniu. Przeprowadzono badania wybranych prac inżynierskich i magisterskich, które zostały napisane na dwóch Wydziałach: Inżynierii Środowiska i Gospodarki Przestrzennej oraz Rolnictwa i Bioinżynierii, na kierunkach Gospodarka przestrzenna oraz Ochrona środowiska. Analizy dokonano w latach 2011-2017.
\end{abstract}

Słowa kluczowe: Systemy Informacji Geograficznej (GIS), edukacja, gospodarka przestrzenna, ochrona środowiska.

\section{Wprowadzenie}

Systemy Informacji Geograficznej (ang. Geographic Information System, GIS) zajmują się danymi o charakterze geograficznym i stanowią element systemu informacji przestrzennej (Ładysz 2015). GIS korzysta z informacji przetworzonej, czyli wtórnej. W zakresie szczegółowości i dokładności odpowiada skali 1:10000 oraz mniejszym, czyli obejmuje mapy mało- $\mathrm{i}$ średnioskalowe. To właśnie szczegółowość przechowywania danych pozwala wyodrębnić GIS z systemów informacji przestrzennej, na które składają się również Systemy Informacji Terenowej SIT ${ }^{1}$.

Systemy Informacji Geograficznej stosuje się również do określenia oprogramowania ułatwiającego przygotowanie map oraz modyfikację już istniejących w oparciu o dostępne dane kartograficzne (Litwin, Myrda 2005). GIS umożliwia tworzenie wszelakich analiz przestrzennych oraz modelowanie (Urbański 2011). Pierwszy System Informacji Geograficznej powstał w 1963 roku. Korzystając z niego, sprawdzono dostępne zasoby naturalne w Kanadzie. W 1970 roku GIS

\footnotetext{
${ }^{1}$ http://www.gisplay.pl (dostęp: 15.10.2018).
} 
umożliwił przeprowadzenie spisu ludności w Stanach Zjednoczonych (Jażdżewska, Urbański 2013). W połowie lat 90 . XX wieku powstały natomiast pierwsze darmowe programy GIS, a w 2002 roku Gary Sherman utworzył Quantum GIS, obecnie QGIS (Pokojska, Pokojski 2017). Obecnie jest to jedna z najbardziej powszechnych aplikacji GIS, która na zasadach wolnego oprogramowania jest dostępna na wiele systemów operacyjnych (Szczepanek 2017). Sukces programu związany jest też z szeroką gamą wtyczek, zapisywanych w języku Python, które umożliwiają tworzenie nowych funkcji (Szczepanek 2012).

Zaletą GIS jest wielofunkcyjność w zakresie możliwych do wykonania czynności. Praca z danymi zaczyna się od ich pozyskania, przechowywania, a w dalszej kolejności umożliwia również weryfikację, przetwarzanie i analizowanie. Informacje o danym obszarze przedstawiają warstwy tematyczne, które pozwalają na scharakteryzowanie obiektów zlokalizowanych w przestrzeni (Kwietniewski, Miszta-Kruk, Wróbel 2007). Za pomocą oprogramowania GIS możliwe jest również odczytywanie i zapisywanie plików w formatach wektorowych i rastrowych, choć pierwotnie przewidywano jedynie te pierwsze (Szczepanek 2012). Funkcjonalność aplikacji opartych o narzędzia GIS jest uzależniona od możliwości ich wykorzystania. Wszystkie opracowania kartograficzne wraz z utworzonymi warstwami tematycznymi prezentowane są jako wykresy, w tym kartogramy, tabele, animacje czy inne rysunki (Kuraś 2007). Programy GIS umożliwiają tym samym realizację najbardziej powszechnych zadań w prosty sposób dla użytkowania (Bednarczyk, Rapiński 2011).

GIS okazuje się również przydatny w ocenie środowiska przyrodniczego, a także w procesie decyzyjnym, uzależnionym od wcześniejszych analiz. W ten sposób odgrywa bardzo ważną rolę w kształtowaniu otaczającego świata (Ewertowski, Tomczyk 2007).

Zazwyczaj dostępne dane zgromadzone w Systemach Informacji Geograficznej, przed dalszym wykorzystywaniem, uzupełniają eksperci z dziedzin geodezji oraz kartografii. Informacje takie powinny spełniać określone wymogi prawne oraz standardy techniczne. Istotne jest to m.in. w administracji samorządowej i rządowej. Urzędnicy, którzy podejmują decyzje w oparciu o takie dane, muszą liczyć się ze skutkami prawnymi oraz finansowymi (Czepkiewicz 2013). Już przy tworzeniu podstawowych dokumentów planistycznych, jakim jest obowiązkowy dokument dla każdej gminy, czyli studium uwarunkowań i kierunków zagospodarowania przestrzennego, a także nieobligatoryjne miejscowe plany zagospodarowania przestrzennego, będące aktem prawa miejscowego, pomocne okazują się funkcje programu GIS (Fogel 2007). Łatwy dostęp do nich przekłada się na jego szerokie zastosowanie. $Z$ jego narzędzi korzystają właśnie pracownicy administracji publicznej na różnych poziomach, przedsiębiorcy w celach komercyjnych, a także naukowcy i studenci. W okresie kształcenia na poziomie wyższym, najszersze wykorzystanie charakteryzuje kierunki o tematyce przyrodniczej, głównie 
z dziedzin zawierających elementy: topografii oraz teledetekcji (Widacki 2004). Pracownicy umysłowi we współczesnym świecie dzięki analizom wykonywanym przy użyciu programu GIS, w oparciu o duże ilości danych dostarczających informacji o przestrzeni, mogą podejmować trafne decyzje (Głowacz 2015). Potrzebnych jest zatem coraz więcej specjalistów, którzy potrafią się umiejętnie posługiwać danymi w zakresie GIS (Fogel 2007).

Bardzo korzystne jest stosowanie w edukacji ekologicznej narzędzi GIS, ponieważ analiza przestrzenna pozwala na lepsze zrozumienie przez uczących się relacji zachodzących pomiędzy ludźmi a środowiskiem, w tym również procesami społecznymi i fizycznymi. W świetle dużej dynamiki zmian, a także sprawdzania zasięgu zjawisk konieczna jest własna praca z dostępnymi danymi, a nie wystarcza jedynie bierne korzystanie z materiałów źródłowych. Mówiąc o kształceniu studentów, należy pamiętać także o przygotowywaniu odpowiednej kadry, która posiada znajomość programów GIS, aby mogła młodych ludzi wprowadzić w tematykę. Obecnie już od najmłodszych lat, co dotyczy szkoły podstawowej, uczniom umożliwia się dostęp do Systemów Informacji Geograficznej (Angiel, Pokojska, Pokojski 2017). Jeśli osoba ucząca się wpływa realnie na wykonanie mapy, pobudza koncentrację w zakresie przestrzennym, a tym samym rozwija sposób konstruktywistycznego sposobu pozyskiwania wiedzy i dalszego kształcenia. Samodzielny dobór informacji do opracowania kartograficznego oraz samego wizualnego wyglądu mapy usprawnia w ten sposób wiele procesów myślowych (Głowacz 2015).

Pojęcia informacji geograficznej zaczęto też używać zamiennie z przestrzenną jako bardziej interdyscyplinarnego określenia powiązania z Ziemią. Ukształtowała to m.in. Unia Europejska, a w Polsce przede wszystkim Dyrektywa INSPIRE (Gaździcki i in. 2018). Systemy Informacji Geograficznej stanowią duży potencjał w aspekcie przestrzennym. Korzystają z nich właśnie osoby zajmujące się planowaniem przestrzennym. Zbiera się niezbędne informacje dotyczące m.in. gruntów, budynków i infrastruktury, a następnie je np. przechowuje i udostępnia (Czepkiewicz 2013). Możliwości zastosowania oprogramowania GIS przede wszystkim w planowaniu przestrzennym są bardzo szerokie. Tworzenie własnych baz danych czy modeli przestrzennych niezwykle uławia operowanie informacją (Kistowski 2003).

Narzędzia GIS zwiększają możliwości, które pozwalają na analizowanie skomplikowanych powiązań zachodzących w środowisku, modelowanie, jak też i opracowywanie prognoz, a także przewidywanie zachodzących zmian. Identyfikację i charakterystykę procesów objętych monitoringiem realizuje się w oparciu o liczne metody za pomocą analiz oraz wizualizacji. Często niestety błędnie kojarzy się oprogramowanie GIS z zastosowaniem w kartografii, co umniejsza możliwości ich wykorzystania. Próbki pobrane z otoczenia oraz w następnej kolejności przebadane mogłyby być bazą do dalszych opracowań i analiz środowiskowych (Gajos, Sierka 2011). 
Celem artykułu było wskazanie możliwości wykorzystania narzędzi Systemów Informacji Geograficznej (GIS) w edukacji na poziomie kształcenia wyższego na przykładzie prac dyplomowych realizowanych na Uniwersytecie Przyrodniczym w Poznaniu.

\section{Metodyka}

W pierwszym etapie prac przeanalizowano opisy, programy oraz efekty kształcenia na dwóch badanych kierunkach studiów: gospodarce przestrzennej i ochronie środowiska. W celu sprawdzenia, jak rozwija się sposób wykorzystania narzędzi GIS w edukacji na poziomie szkolnictwa wyższego, zapoznano się z udostępnionymi przez promotorów pracami dyplomowymi: inżynierskimi i magisterskimi realizowanymi na Uniwersytecie Przyrodniczym w Poznaniu, na Wydziale Inżynierii Środowiska i Gospodarki Przestrzennej oraz Rolnictwa i Bioinżynierii. Analizie poddano 200 prac. Najpierw zweryfikowano, w których pracach zastosowano narzędzia GIS. Kolejną czynnością było sprawdzenie, w jakim zakresie wystąpiło ich wykorzystanie, czy tylko do przedstawienia informacji czy też do przetworzenia i analizy danych.

Do oceny poziomu zaawansowania GIS w kształceniu studentów zastosowano podział opracowany przez A. Głowacza (2015). Prace podzielono na cztery poziomy zastosowania GIS. Są to czynności od wykorzystania dostępnych materiałów kartograficznych w postaci map, przez prezentację już przetworzonych informacji, w kolejnych etapach uzupełnienie ich o pozyskane podczas badań terenowych lub z innych dostępnych źródeł, do analizy danych o przestrzeni, co łączy się $\mathrm{z}$ opracowaniem własnych map (ryc. 1).

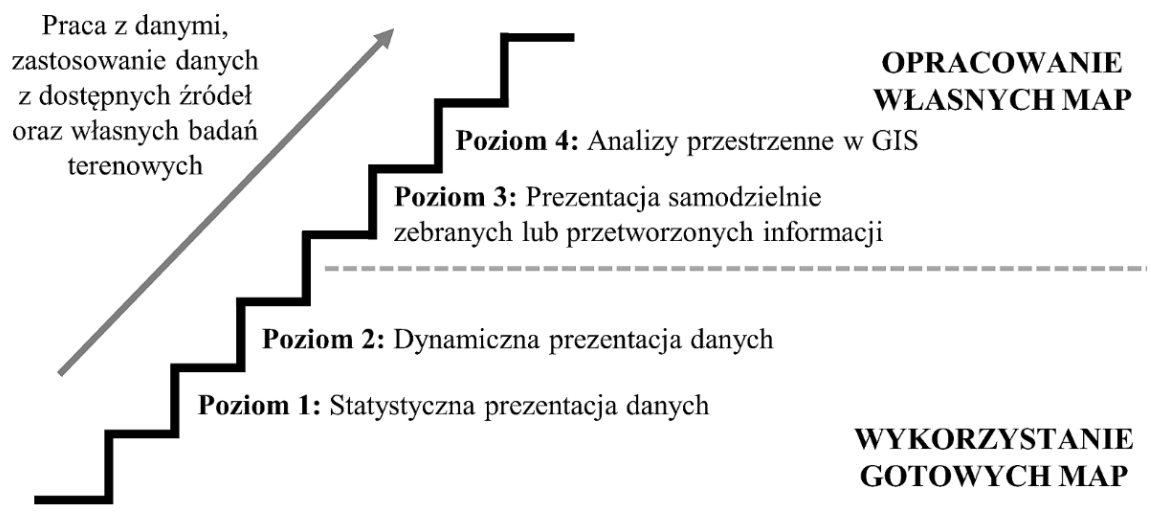

Ryc. 1. Poziomy zaawansowania GIS w kształceniu studentów Źródło: opracowanie własne na podstawie: A. Głowacz (2015). 
Na podstawie zebranych danych wykonano wykresy przedstawiające procentowo zastosowanie GIS w pracach inżynierskich i magisterskich z podziałem na kierunki w ogólnej liczbie analizowanych prac. W tabeli 1 i 2 zamieszczono przykładowe tematy prac dyplomowych, a na ryc. 6 opracowanie mapowe wykonane przez jednego z dyplomantów w programie QGIS.

\section{Wyniki}

Zgodnie z efektami kształcenia dla kierunku studiów ochrona środowiska i ich odniesienia do efektów obszarowych, absolwent posiada następującą umiejętność: „wykorzystuje Systemy Informacji Geograficznej (GIS) jako podstawowe narzędzie do tworzenia baz danych o środowisku" (Uchwała nr 377/2012, Załącznik do uchwały nr 377/2012 Senatu UP; Uchwała nr 48/2013, Załącznik nr 1 do uchwały nr 48/2013 Senatu UP). Jak widać, poznanie oprogramowania GIS jest nieodłączne w trakcie kształcenia. Dotyczy to studiów inżynierskich, a kontynuowane jest na magisterskich. Po przeprowadzeniu badań okazuje się jednak, że studenci sporadycznie wykorzystują GIS w przygotowywanych pracach dyplomowych i bazują na mapach już opracowanych i udostępnionych. Z kolei efekty kształcenia dla kierunku gospodarka przestrzenna i ich odniesienie do efektów obszarowych oraz kompetencji inżynierskich są sformułowane bardziej ogólnie dla Systemów Informacji Przestrzennej, jednak jego narzędzia umożliwią szybką ich realizację (Uchwała nr 206/2014, Załącznik do uchwały nr 206/2014 Senatu UP; Uchwała nr 374/2016, Załącznik do uchwały nr 374/2016 Senatu UP). Prace badawcze potwierdzają szerokie możliwości zastosowania narzędzi GIS. Zgodnie z Programem studiów stacjonarnych na kierunku gospodarka przestrzen$n a$, na trzecim semestrze trwania edukacji, studenci mają przedmiot Geograficzne systemy informacji przestrzennej w wymiarze łącznie 150 godzin, a w tym 30 godzin ćwiczeń i 30 godzin wykładów oraz 9 godzin innych z udziałem nauczyciela i 81 godzin pracy własnej. Z kolei zajęcia dla studentów niestacjonarnych zostały pomniejszone do 20 godzin ćwiczeń i 20 godzin wykładów. Wiedza zdobyta na tym przedmiocie jest przydatna później na innych przedmiotach, wykorzystywana m.in. przy wykonywaniu projektów o różnej tematyce związanej z planowaniem i zagospodarowaniem przestrzennym, np. fizjografii, gleboznawstwie i gospodarce gruntami, teledetekcji czy rynku i wycenie nieruchomości rolnych i leśnych. Z kolei studenci kierunku ochrona środowiska, zgodnie z programem studiów, na piątym semestrze mają przedmiot teledetekcja i GIS w wymiarze łącznie 102 godzin, w tym 15 godzin wykładów i 30 godzin ćwiczeń, 8 godzin zajęć innych z udziałem nauczyciela oraz 49 godzin pracy własnej.

W opisie kierunku gospodarka przestrzenna absolwent w okresie trwania studiów zdobywa wiedzę, a także umiejętności, które umożliwią: opracowywanie dokumentów planistycznych przygotowywanych przez władze lokalne, 
m.in. miejscowych planów zagospodarowania przestrzennego, studiów uwarunkowań i kierunków zagospodarowania przestrzennego, a także strategii rozwoju regionów czy gmin i programów rewitalizacji o zasięgu lokalnym oraz ofert o charakterze inwestycyjnym. Absolwent będzie mógł brać udział w sprawnym zarządzaniu miastami, jak również większymi jednostkami samorządu terytorialnego, czyli gminą, powiatem, województwem oraz krajem.

Osoba, która podejmie studia na kierunku gospodarka przestrzenna, nauczy się zasad niezbędnych do kształtowania środowiska w sposób zrównoważony oraz z zachowaniem ładu przestrzennego. Będzie to możliwe dzięki zdobyciu umiejętności w zakresie oceny zasobów i stanu środowiska przyrodniczego, gospodarowania gruntami i obsługi aplikacji GIS, czyli Systemów Informacji Przestrzennej oraz programów CAD, wykorzystywanych do projektów technicznych.

Główne miejsca pracy absolwentów kierunku gospodarka przestrzenna znajdują się w sektorze publicznym, czyli administracji rządowej oraz samorządach lokalnych, co dotyczy przede wszystkim wydziałów związanych z planowaniem oraz zagospodarowaniem przestrzennym, architekturą, urbanistyką, ochroną środowiska i zajmujących się planowaniem rozwoju gospodarczego i promocji. Szeroka gama możliwości jest również w sektorze prywatnym, obejmującym m.in. agencje rozwoju, pracownie architektoniczne, planistyczne i urbanistyczne, agencje wyceny nieruchomości, przedsiębiorstwa z branży doradczych i konsultingowych.

Opis kierunku ochrona środowiska zwraca uwagę na to, że studenci w okresie studiów mogą zdobyć niezbędną wiedzę obejmującą zagadnienia z dziedziny ochrony oraz kształtowania środowiska. Dotyczy ona m.in. dziedzin przyrodniczych, organizowania ochrony środowiska, a w tym zakresie identyfikacji i monitorowania występujących zagrożeń oraz podejmowania na tej podstawie dalszych kroków, np. programowania i niezbędnych działań, które umożliwią przywrócenie równowagi w otoczeniu.

Absolwent, który ukończył studia na kierunku ochrona środowiska będzie mógł pracować w przedsiębiorstwach, których obszarem zainteresowań jest ochrona środowiska, np. inspekcjach, jednostkach naukowych czy badawczych, instytucjach, które finansują działania na rzecz ochrony środowiska, przedsiębiorstwach o charakterze eksperckim i doradczym, a także w sektorze publicznym obejmującym administrację samorządową czy rządową.

Kierunek ochrona środowiska można nazwać interdyscyplinarnym, ponieważ integruje tematykę z zakresu m.in. klimatologii i meteorologii, biochemii, monitoringu środowiska, aspektów prawnych oraz ekonomicznych ochrony środowiska i przyrody, ekologii, geochemii i gleboznawstwa oraz waloryzacji siedlisk.

Po wykonaniu badań można stwierdzić, że w pracach dyplomowych realizowanych na kierunku gospodarka przestrzenna największe jest wykorzystanie narzędzi GIS. Prace inżynierskie na przestrzeni badanych lat w prawie 88,73\% powstały w oparciu o programy GIS (ryc. 2). Nieco słabsze wyniki odnotowano 
dla prac magisterskich, jednak to nadal wysoki wynik wynoszący $82,35 \%$. Z kolei na kierunku ochrona środowiska bardzo mało dyplomantów skorzystało z oprogramowania QGIS. W pracach inżynierskich na przestrzeni analizowanych lat GIS zastosowano w 35\%, a w magisterskich jedynie 1,92\% ogółu wszystkich prac.

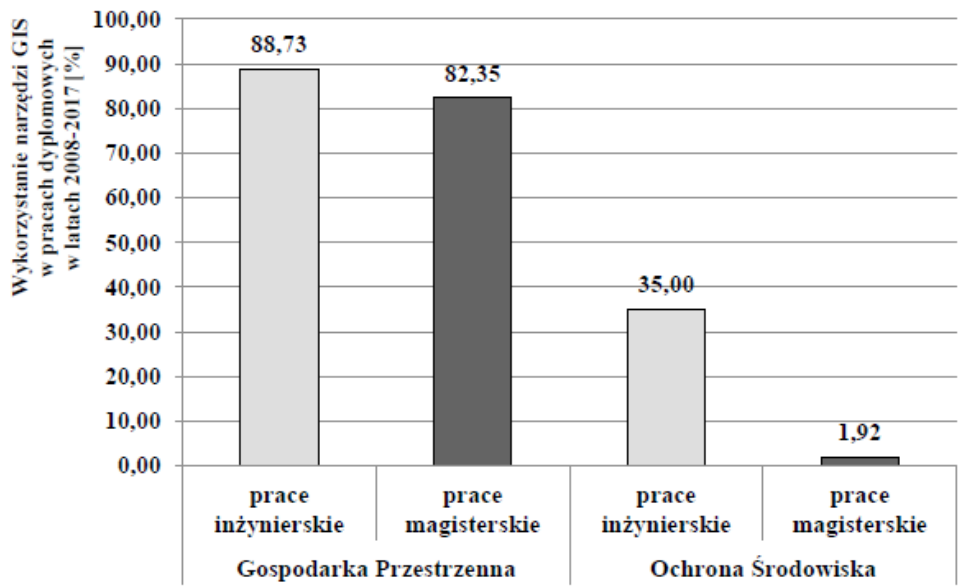

Ryc. 2. Ogólne wykorzystanie narzędzi GIS w pracach dyplomowych realizowanych na kierunkach Gospodarka przestrzenna i Ochrona środowiska w latach 2011-2017 Źródło: opracowanie własne.

Analizując poziomy zastosowania narzędzi GIS w obrębie wszystkich badanych prac $\mathrm{z}$ danego kierunku, z podziałem na pierwszy i drugi stopień, czyli studia inżynierskie i magisterskie, również zauważono różnice (ryc. 3). Gospodarka przestrzenna charakteryzuje się występowaniem wyższych poziomów związanych z samodzielnym przygotowaniem map, a więc prezentacją zgromadzonych przez siebie danych (poziom III) i w dalszej kolejności przetworzonych oraz analizą (poziom IV). Z kolei na ochronie środowiska dyplomanci w większym zakresie wykorzystują już istniejące mapy poprzez statyczne (poziom I) oraz dynamiczne przedstawianie informacji (poziom II).

W pracach dyplomowych realizowanych na kierunku gospodarka przestrzen$n a$, działaniami charakterystycznymi dla poziomu III wykazało się $42,25 \%$ na studiach inżynierskich i $25,53 \%$ studiów magisterskich. Z kolei na ochronie środowiska wartości te są znikome. Jedynie w pracach inżynierskich sięgają 5\%, a w pracach magisterskich nie pojawiają się wcale. Najwyższy poziom spośród wszystkich, czyli IV, występuje w pracach magisterskich na kierunku gospodarka przestrzenna, osiągając wynik 41,18\%. Na studiach inżynierskich 18,31\% ogółu badanych prac można wpisać do poziomu IV. Na ochronie środowiska nie występuje w ogóle poziom IV. 


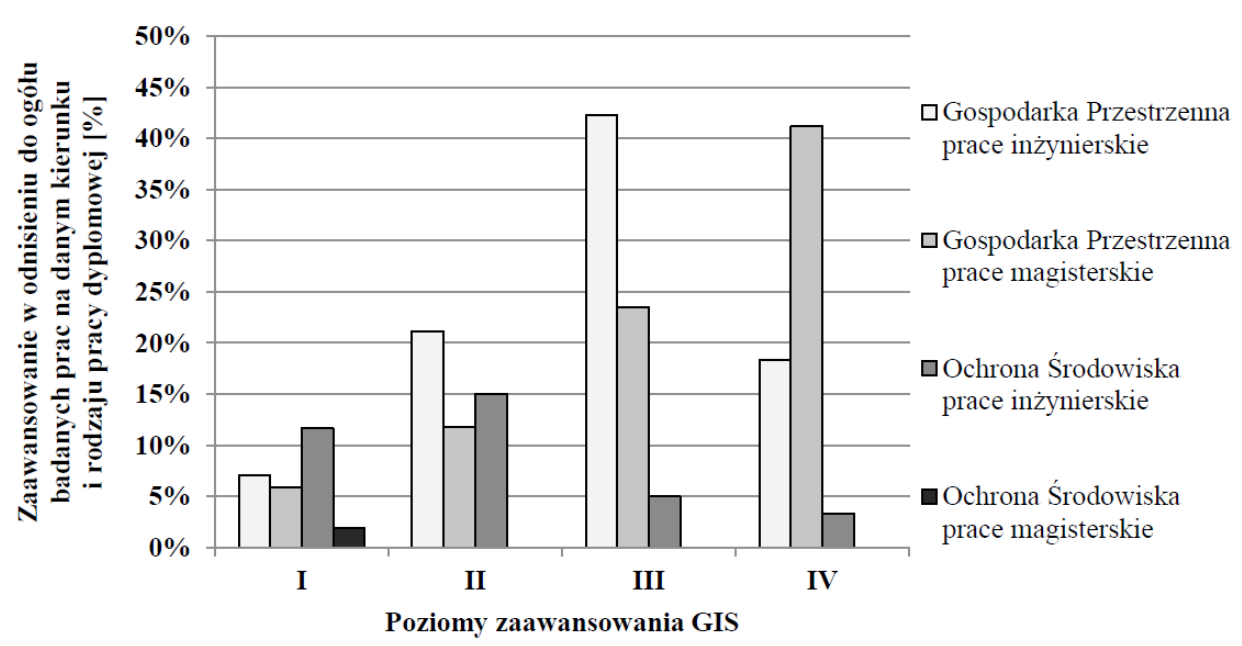

Ryc. 3. Poziomy zastosowania narzędzi GIS w pracach dyplomowych realizowanych na kierunkach Gospodarka przestrzenna i Ochrona środowiska w latach 2011-2017 Źródło: opracowanie własne.

Niższe stopnie zaawansowania narzędzi GIS związane z wykorzystaniem już dostępnych materiałów kartograficznych charakteryzują w większym stopniu ochronę środowiska. Ogólne wykorzystanie programów GIS na tym kierunku nie jest wysokie (ryc. 3), co odzwierciedla się w niskim udziale we wszystkich poziomach. Najwięcej dyplomantów reprezentowało II stopień, czyli dynamiczną prezentację danych, osiągając wynik $15 \%$ dla prac inżynierskich. Nieco mniej, $11,67 \%$, zalicza się do poziomu I. Słabiej wypada to na studiach magisterskich, co uwarunkowane jest niskim zastosowaniem narzędzi GIS w tych pracach. Na gospodarce przestrzennej II poziom zaawansowania reprezentuje $21,13 \%$ ogótu analizowanych prac inżynierskich, a 11,76\% magisterskich. Poziom I na gospodarce przestrzennej charakteryzuje najmniejszy udział prac, sięgając jedynie $7,04 \% \mathrm{w}$ pracach inżynierskich.

Często realizowane tematy niekoniecznie wymagały zastosowania narzędzi GIS, jednak pojawiały się w nich mapy pozyskane z dostępnych źródeł, m.in. ze strony internetowej geoportal.gov.pl, Google Earth, Wojewódzkiego Inspektoratu Ochrony Środowiska, Krajowego Zarządu Gospodarki Wodnej oraz innych posiadających w swoich zasobach dane kartograficzne. W nielicznych przypadkach opracowano własne mapy, jednak przy użyciu innych programów graficznych, np. GIMP, AutoCAD czy CorelDRAW. Dotyczyło to głównie dyplomantów Ochrony Środowiska, którzy mają mniejsze doświadczenie związane z obsługą programów GIS zdobytą w czasie trwania studiów. 
Analizując zastosowanie narzędzi GIS w pracach dyplomowych realizowanych na gospodarce przestrzennej (ryc. 4) i ochronie środowiska (ryc. 5), można zauważyć, że sukcesywnie zwiększa się zastosowanie oprogramowania GIS na każdym z badanych kierunków. Na gospodarce przestrzennej preferowaną aplikacją jest QGIS, natomiast na ochronie środowiska stosuje się również MapInfo Professional. Największe wykorzystanie występuje na pierwszym stopniu gospodarki przestrzennej, czyli studiów inżynierskich, osiągając wartość 100\% $\mathrm{w}$ latach 2015-2017. Kierunek studiów gospodarka przestrzenna uruchomiono na Wydziale Inżynierii Środowiska i Gospodarki Przestrzennej w 2008 roku, a pierwsze obrony prac inżynierskich odbywały się w roku 2011. Narzędzia GIS były wykorzystywane wówczas tylko w niektórych pracach dyplomowych, w około 35\% ogółu wszystkich analizowanych, a stopniowo ten udział się zwiększał.

Obecnie wszyscy dyplomanci kierunku gospodarka przestrzenna stosują w swoich pracach Systemy Informacji Geograficznej. Dyplomanci w aplikacji komputerowej wykonują przynajmniej proste mapy, np. z lokalizacją terenu do charakterystyki obszarów objętych analizą. Na drugim stopniu studiów programy GIS wykorzystują w nieco mniejszej skali. Wynika to z bardziej naukowej specyfiki tematów prac dyplomowych. Nie mają już charakteru twórczego, koncepcyjnego czy projektowego, a dominuje tutaj kierunek analityczny. $\mathrm{Z}$ biegiem lat narzędzia GIS mają zastosowanie do coraz bardziej skomplikowanych analiz przestrzennych. Drugi stopień kierunku studiów gospodarka przestrzenna na Wydziale Inżynierii Środowiska i Gospodarki Przestrzennej rozpoczął się w 2015 roku. Pierwsze obrony prac magisterskich odbyły się w 2016 roku. Zastosowanie narzędzi GIS w nich było już na wysokim poziomie i już wtedy stanowiło około $95 \%$ ogółu prac. Warto zauważyć, że na studiach magisterskich przeważają studenci, którzy kształcili się na I stopniu na tej samej uczelni, natomiast osoby wywodzące się z innej uczelni nie przekraczają $5 \%$, co obserwowane jest także na studiach magisterskich kierunku ochrona środowiska.

Na kierunku studiów ochrona środowiska również zwiększa się wykorzystanie oprogramowania GIS, jednak jest kilkukrotnie mniejsze niż na gospodarce przestrzennej (ryc. 5). Pierwsze obrony prac inżynierskich odbyły się w 2011 roku. Wówczas jedynie 20\% dyplomantów zastosowało programy GIS w swojej pracy, do 2014 roku nieznacznie zwiększyło się ich wykorzystanie. W 2015 roku osiągnęło 50\% i w ostatnim badanym roku 2017 wyniosło 60\%. Z kolei w pracach magisterskich również w tym samym roku osiągnęło niski wynik $20 \%$. W latach wcześniejszych dyplomanci w ogóle nie stosowali w swoich pracach magisterskich narzędzi GIS, co uwarunkowane było głównie badawczym ich charakterem, m.in. polegającym na wykonaniu analiz chemicznych oraz oceny środowiska. 


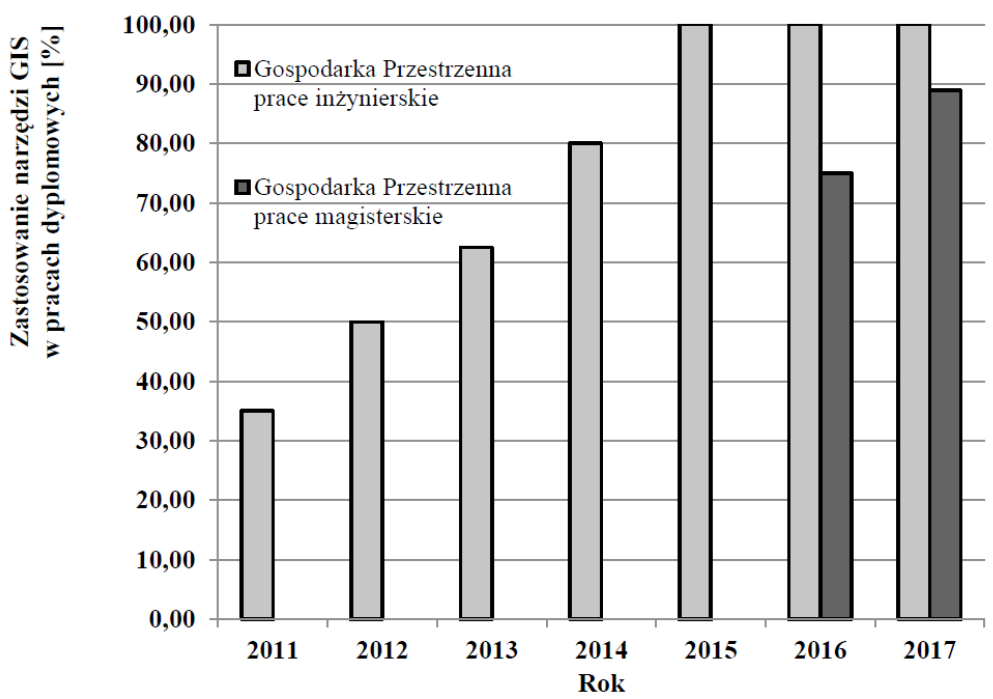

Ryc. 4. Zastosowanie narzędzi GIS w pracach dyplomowych realizowanych na kierunku Gospodarka przestrzenna na Uniwersytecie Przyrodniczym w Poznaniu w latach 2011-2017

Źródło: opracowanie własne.

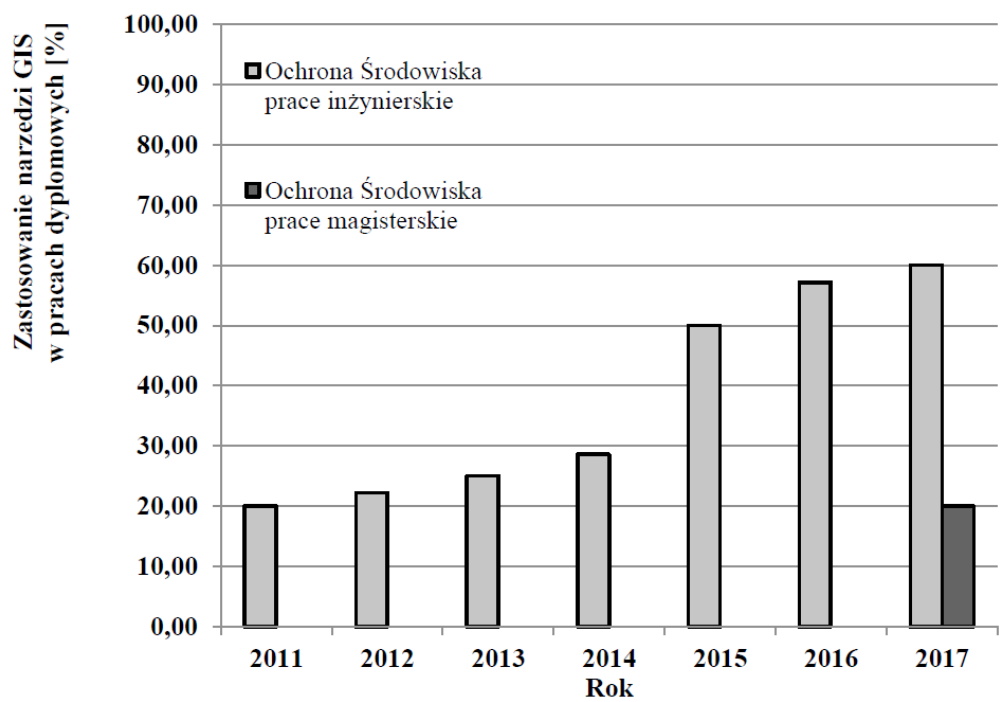

Ryc. 5. Zastosowanie narzędzi GIS w pracach dyplomowych realizowanych na kierunku Ochrona środowiska na Uniwersytecie Przyrodniczym w Poznaniu w latach 2011-2017

Źródło: opracowanie własne. 
Tematyka realizowanych prac dyplomowych na analizowanych kierunkach była odmienna. W pracach inżynierskich na gospodarce przestrzennej przeważały tematy koncepcyjne dotyczące m.in. zagospodarowania przestrzennego, rewitalizacji czy też wzbogacenia potencjału turystycznego. Studenci na potrzeby wykonania projektów, opracowywali mapy z zaznaczeniem badanych terenów, strukturą użytkowania, inwentaryzacją zasobów, co jest związane ze środowiskiem przyrodniczym i kulturowym, umiejscowieniem form ochrony przyrody, wodami gruntowymi czy pokrywą glebową. Dokonywali również waloryzacji obszarów. W planowanym zagospodarowaniu turystyczno-rekreacyjnym, w celu dokonania trafnego wyboru kierunków rozwoju, przeprowadzono waloryzację przyrodniczo-krajobrazową. Często takie działanie dotyczyło całej miejscowości lub gminy. Na podstawie przeprowadzonych waloryzacji zaproponowano następnie rozmieszczenie szlaków rowerowych, pieszych i konnych (tab. 1). Wyróżniano również strefy urbanistyczne w miastach, korzystając z transektów liniowych i metryk krajobrazowych (ryc. 6).

Tabela 1. Przykładowe tematy prac dyplomowych inżynierskich i magisterskich realizowanych na kierunku Gospodarka przestrzenna

Przykładowe tematy prac dyplomowych

Zmiana struktury przestrzennej strefy przybrzeżnej wybranych jezior

Zagospodarowanie przestrzenne zlewni wybranych jezior

Waloryzacja i ocena krajobrazu na potrzeby planowania przestrzennego gminy

Użytkowanie gruntów w strefie przybrzeżnej i zlewni bezpośredniej jezior

Zmiany użytkowania gruntów w zlewniach jezior

Analiza i koncepcja zagospodarowania przestrzennego zlewni bezpośredniej jezior

Ocena stanu ochrony obiektów archeologicznych w wybranej gminie

Koncepcja rozwoju turystyki w wybranym mieście

Porównanie atrakcyjności rekreacyjnej jezior i koncepcja rozwoju infrastruktury turystycznej

Planistyczne metody ograniczania ryzyka powodziowego w wybranej gminie

Planistyczne metody ograniczania ryzyka występowania susz w wybranej gminie

Analiza zmian cen transakcyjnych gruntów niezabudowanych wybranej gminy

Analiza porównawcza aktualnego zagospodarowania terenów wokół jezior położonych w wybranej gminie

Przestrzenne aspekty suburbanizacji w wybranej gminie

Identyfikacja i porównanie struktur przestrzennych wybranych miast

Źródło: wybór tematów dokonany przez autorów $\mathrm{z}$ tematów prac realizowanych $\mathrm{w}$ latach 2011-2017. 


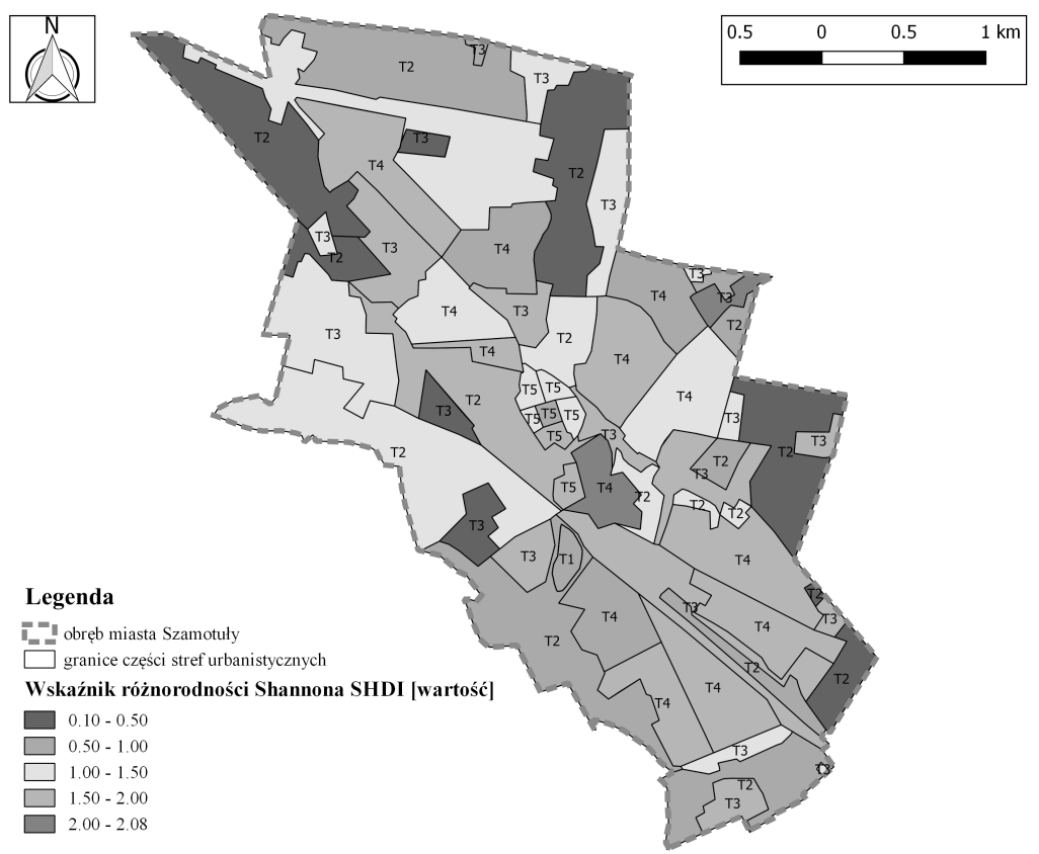

Ryc. 6. Przykład zastosowania narzędzi GIS w pracy dyplomowej. Wskaźnik różnorodności Shannona SHDI dla miasta Szamotuły Źródło: P. Hoffmann (2018).

Na kierunku studiów ochrona środowiska, tematy prac dyplomowych są bardziej ukierunkowane na biologię oraz przyrodę. Często badane są zjawiska zachodzące $\mathrm{w}$ środowisku, zanieczyszczenia powietrza czy powiązania pomiędzy gatunkami, dlatego na potrzeby prac inżynierskich oraz magisterskich przeprowadza się badania terenowe czy laboratoryjne, w celu dokładniejszej analizy materiałów. Studenci gospodarki przestrzennej natomiast rzadko pracują w laboratorium, co wynika z odmiennej specyfiki kierunku (tab. 2).

Tabela 2. Przykładowe tematy prac dyplomowych inżynierskich i magisterskich realizowanych na kierunku Ochrona środowiska

Przykładowe tematy prac dyplomowych

Waloryzacja przyrodnicza dla celów rewitalizacji wybranej gminy

Zastosowanie makrofitów a rekultywacja jezior

Osady denne jako narzędzie rekultywacji jezior

Stan i sposoby renaturyzacji torfowiska przejściowego

Wpływ form użytkowania rekreacyjnego jezior na roślinność wodną 
Inwentaryzacja zagrożeń środowiska wynikających z niewłaściwej praktyki rolniczej

Wykorzystywanie makrofitów w detrofizacji jezior

Wpływ dostosowania biogenów w osadach rzecznych na produktywność makrofitów

Ocena stanu hydromorfologicznego sztucznych akwenów

Ocena stanu ekologicznego jeziora i metody ochrony

Ocena skuteczności działań rekultywacyjnych jeziora

Ocena przydatności rekreacyjnej jeziora

Ocena stanu zanieczyszczenia powietrza oraz wskazanie sposobów ograniczania ich rozprzestrzeniania się na terenie wybranego miasta

Charakterystyka reakcji wybranych gatunków roślin bioindykacyjnych na obecność ozonu troposferycznego

Analiza potencjału rozwoju energetyki wiatrowej wybranej gminy

Źródło: wybór tematów dokonany przez autorów z tematów prac realizowanych w latach 2011-2017.

\section{Podsumowanie i wnioski}

Zauważono tendencję wzrostową wykorzystania programów GIS w pracach inżynierskich i magisterskich obu kierunków studiów. W związku z tym prognozowane jest zwiększające się zastosowanie tego narzędzia na etapie kształcenia studentów oraz w przyszłej pracy zawodowej absolwentów uczelni, jak również samo zapotrzebowanie na osoby z takimi umiejętnościami. W przestrzeni zachodzą szybkie zmiany, dlatego niezwykle ważna jest wnikliwa i bieżąca analiza dostępnych informacji. Absolwenci kierunku studiów gospodarka przestrzenna są dobrze przygotowani do pracy z programami GIS, co uwidacznia się w pracach dyplomowych ich autorstwa. Wpływa na to również fakt, że coraz więcej dostępnych informacji o przestrzeni powstało w oparciu o Systemy Informacji Geograficznej. Z kolei osoby, które ukończyły ochronę środowiska, pomimo odpowiedniego przygotowania do wykorzystywania narzędzi GIS w pracy dyplomowej, nie stosują ich powszechnie - głównie do pracy na mapach już istniejących. W pracach dyplomowych realizowanych na gospodarce przestrzennej pojawiaja się bardziej skomplikowane analizy przestrzenne i ich formy prezentacji. Umiejętność ta może być przydatna w wykonywanym w przyszłości zawodzie, a nawet wymagana przez pracodawcę. Jednym z przykładów mogą być oceny oddziaływania na środowiska, które należy tworzyć w celu sprawdzenia, jakie dane przedsięwzięcie może wywoływać skutki w otoczeniu, m.in. przy opracowywaniu dokumentów planistycznych przez władze lokalne, prawnie wymagające prezentacji zjawiska w formie graficznej. Zastosowanie narzędzi GIS jest zatem niezbędne. 
Przy obecnych niebezpieczeństwach związanych z degradacją środowiska, trzeba monitorować negatywne działanie dla społeczeństwa oraz świata przyrody. Kształcenie w zakresie ekologii i ochrony środowiska będzie przy tym niezbędne, a także odniesienie zjawisk do zmian zachodzących w przestrzeni i w czasie, co z kolei umożliwia modelowanie za pomocą narzędzi GIS. Dotyczy to występowania np. zanieczyszczeń, a także zasięgu poszczególnych gatunków organizmów. Sprawne wykrycie powiązań przyczynowo-skutkowych może być niekiedy niezwykle cenne i zapobiec degradacji środowiska.

Uzyskane wyniki wskazują, że na kierunku ochrona środowiska należy poprawić jakość kształcenia w zakresie oprogramowania GIS. Na gospodarce przestrzennej już od paru lat przyjęło się, że do opracowań kartograficznych i nie tylko wykorzystuje się GIS. Trzeba jednak dbać o to, aby nie zatracić wypracowanej dobrej praktyki nauczania i dalej edukować młodych ludzi oraz pokazywać jak umiejętnie wykonywać analizy przestrzenne. Dużo zależy właśnie od wykwalifikowanej kadry, która wprowadzi studentów do oprogramowania GIS i pozwoli zapoznać się z jego funkcjami.

Przeprowadzone badania uświadamiają, że należy stale poszerzać wiedzę i zdobywać nowe umiejętności w zakresie obsługi programów komputerowych, a przede wszystkim tak przydatnych, jak: QGIS, MapInfo czy ArcGIS. Należy jednak zauważyć, że znacznie zyskuje też WebGIS stanowiący wzorzec do projektowania narzędzi GIS-owych. Uaktualnienie baz danych w oparciu o Systemy Informacji Przestrzennej ułatwia do nich dostęp i sprawia, że stają się one z dnia na dzień coraz bardziej powszechne.

\section{Literatura}

Angiel J., Pokojska P., Pokojski W., 2017, Szanse, cele i możliwości edukacji ekologicznej nauczycieli z wykorzystaniem mediów $i$ WebGIS, ,Polish Journal of Countinuing Education", 2: 52-62.

Bednarczyk M., Rapiński J., 2011, Wykorzystanie oprogramowania Open Source w pomiarach bezpośrednich, „Roczniki Geomatyki”, Polskie Towarzystwo Informacji Przestrzennej, 9-3(47): 25-35.

Czepkiewicz M., 2013, Systemy informacji geograficznej w partycypacyjnym zarzadzaniu przyrodą w mieście, „Zrównoważony Rozwój. Zastosowania”, 4: 111-123.

Ewertowski M., Tomczyk A., 2007, Ocena stanu środowiska geograficznego szlaków turystycznych - wykorzystanie GIS do integracji i analizy danych terenowych $i$ kartograficznych, „Przegląd Geograficzny”, 79(2): 271-295.

Fogel P., 2007, Bazy danych GIS w planowaniu przestrzennym na poziomie lokalnym, „Roczniki Geomatyki”, Polskie Towarzystwo Informacji Przestrzennej, 5(7): 39-45.

Gajos M., Sierka E., 2011, Kierunki badań zastosowania technologii GIS w Ochronie Środowiska: Analiza polskiego czasopiśmiennictwa naukowego, „Roczniki Geomatyki”, Polskie Towarzystwo Informacji Przestrzennej, 9-3(47): 61-70. 
Gaździcki J. i in., 2018, Current aspects of geospatial education in Poland, „Roczniki Geomatyki”, Polskie Towarzystwo Informacji Przestrzennej, 16-3(82): 241-246.

Głowacz A., 2015, Teoretyczne i praktyczne aspekty wykorzystania GIS w szkolnej edukacji geograficznej, „Prace Komisji Edukacji Geograficznej PTG”, 5, Łódź: 73-88.

Hoffmann P., 2018, Identyfikacja i porównanie struktur przestrzennych Szamotut i Środy Wielkopolskiej. Praca magisterska.

Jażdżewska I., Urbański J., 2013, GIS w nauce, „Acta Universitatis Lodziensis. Folia Geographica Socio-Oeconomica”, 14, Wydawnictwo Uniwersytetu Łódzkiego, Łódź: $5-15$.

Kistowski M., 2003, Struktury i przepływy informacji przyrodniczej na potrzeby planowania przestrzennego, „Człowiek i Środowisko”, 27(1-2): 83-96.

Kuraś B., 2007, Wykorzystanie GIS jako kompleksowego narzędzia waloryzacji środowiska przyrodniczego pod kątem planowania przestrzennego zagospodarowania terenu, Archiwum Fotogrametrii, Kartografii i Teledetekcji, 17b: 425-435.

Kwietniewski M., Miszta-Kruk K., Wróbel K., 2007, Możliwości zastosowania GIS $w$ wodociagach na przykładzie wybranego systemu dystrybucji wody, „Ochrona Środowiska", 29(3): 73-76.

Litwin R., Myrda G., 2005, Systemy Informacji Geograficznej. Zarzadzanie danymi przestrzennymi w GIS, SIP, SIT, LIS, Helion, Gliwice.

Ładysz J., 2015, Technologia GIS w Inżynierii Bezpieczeństwa, Wydawnictwo Wyższej Szkoły Oficerskiej Wojsk Lądowych im. generała Tadeusza Kościuszki, Wrocław.

Pokojska P., Pokojski W., 2017, Wolne oprogramowanie QGIS i jego możliwości wykorzystania w edukacji, „Edukacja-Technika-Informatyka”, 4(22), Rzeszów: 335-340.

Szczepanek R., 2012, Quantum GIS - wolny i otwarty System Informacji Geograficznej, „Środowisko. Czasopismo Techniczne”, 4, Wydawnictwo Politechniki Poznańskiej, Kraków: 171-182.

Szczepanek R., 2017, Systemy informacji przestrzennej z QGIS część I i II. Podręcznik akademicki, Wydawnictwo Politechniki Krakowskiej, Kraków.

Urbański J., 2011, GIS w badaniach przyrodniczych, Wydawnictwo Uniwersytetu Gdańskiego, Gdańsk.

Widacki W., 2004, Systemy Informacji Geograficznej w programach edukacyjnych uniwersyteckich studiów przyrodniczych $w$ Polsce, ,Roczniki Geomatyki”, Polskie Towarzystwo Informacji Przestrzennej, 2(3): 11-23.

\section{Akty prawne}

Uchwała nr 377/2012 Senatu Uniwersytetu Przyrodniczego w Poznaniu z dnia 29 czerwca 2012 roku w sprawie: określenia efektów kształcenia dla kierunku ochrona środowiska o profilu ogólnoakademickim prowadzonego na poziomie studiów pierwszego stopnia na Wydziale Rolnictwa i Bioinżynierii.

Uchwała nr 48/2013 Senatu Uniwersytetu Przyrodniczego w Poznaniu z dnia 30 stycznia 2013 roku w sprawie: określenia efektów kształcenia dla kierunku ochrona środowiska o profilu ogólnoakademickim prowadzonego na poziomie studiów drugiego stopnia na Wydziale Rolnictwa i Bioinżynierii.

Uchwała nr 206/2014 Senatu Uniwersytetu Przyrodniczego w Poznaniu z dnia 29 października 2014 roku w sprawie: utworzenia kierunku gospodarka przestrzenna na 
poziomie studiów drugiego stopnia, prowadzonego na Wydziale Melioracji i Inżynierii Środowiska oraz określenia efektów kształcenia.

Uchwała nr 374/2016 Senatu Uniwersytetu Przyrodniczego w Poznaniu z dnia 25 maja 2016 roku w sprawie: zmiany Uchwały nr 397/2012 Senatu Uniwersytetu Przyrodniczego w Poznaniu z dnia 29 czerwca 2012 roku w sprawie określenia efektów kształcenia dla kierunku gospodarka przestrzenna o profilu ogólnoakademickim prowadzonego na poziomie studiów pierwszego stopnia na Wydziale Melioracji i Inżynierii Środowiska.

Załącznik do Uchwały nr 377/2012 Senatu UP, Efekty kształcenia dla kierunku studiów ochrona środowiska i ich odniesienie do efektów obszarowych.

Załącznik nr 1 do Uchwały nr 48/2013 Senatu UP, Efekty kształcenia dla kierunku studiów ochrona środowiska i ich odniesienie do efektów obszarowych.

Załącznik do Uchwały nr 206/2014 Senatu UP, Efekty kształcenia na kierunku studiów gospodarka przestrzenna i ich odniesienie do efektów obszarowych.

Załącznik do Uchwały nr 374/2016 Senatu UPP, Efekty kształcenia na kierunku studiów gospodarka przestrzenna i ich odniesienie do efektów obszarowych oraz kompetencji inżynierskich.

\title{
Źródło internetowe
}

http://www.gisplay.pl/gis/definicje-gis.html.

\section{THE APPLICATION OF GIS TOOLS IN EDUCATION FROM THE SCOPE OF THE SPATIAL MANAGEMENT AND ENVIRONMENTAL PROTECTION}

\begin{abstract}
The aim of the study was to indicate the possibility of using the tools of spatial information systems (GIS) in education at the higher education level based on graduate theses realized at the Poznań University of Life Sciences. Research was carried out on selected bechelor and master's theses which had been written at the faculties of Environmental Engineering and Spatial Management and Agriculture and Bioengineering, on Spatial Management and Environmental Protection courses. The years 2008-2017 were analyzed.
\end{abstract}

Keywords: Geographic Information Systems (GIS), education, spatial management, environmental protection.

Mgr inż. Paulina Hoffmann

Mgr inż. Marta Lisiak

Dr hab. inż. Klaudia Borowiak

Katedra Ekologii i Ochrony Środowiska Wydział Inżynierii Środowiska i Gospodarki Przestrzennej

Uniwersytet Przyrodniczy w Poznaniu e-mail: paulina.hoffmann@up.poznan.pl e-mail: marta.lisiak@up.poznan.pl e-mail: klaudia.borowiak@up.poznan.pl 